\title{
METROPOLITAN INNOVATION SYSTEMS: A COMPARISON BETWEEN BARCELONA, STOCKHOLM, AND VIENNA
}

\author{
JAVIER ReVILLA DIEZ \\ Department of Economic Geography, University of Hannover, Germany, \\ diez@wigeo.uni-hannover.de
}

\begin{abstract}
This article uses data from the European Regional Innovation Survey to provide insights into the innovative activity and innovation networking of the most important innovation actors, namely manufacturing firms, producer service firms, and research institutes. The innovation capacities of the metropolitan innovation systems differ markedly. In respect to cooperation partners, vertical relationships predominate. Only in Stockholm do research institutes play a significant role in assisting innovation processes in manufacturing firms. Spatial proximity of cooperation partners is very important, confirming the concept of territorially based systems of innovation. At the same time, the actors surveyed cooperate intensively with cooperation partners outside the region.
\end{abstract}

Metropolitan regions are increasingly seen as regional development engines in a globalizing world (Huggins 1997). On one hand, traditional approaches have explained that metropolitan regions are able to facilitate agglomeration economies in the form of urbanization and localization economies to its actors. On the other hand, they function as gateways to other regions, thus linking the local actors with national or international ones. With respect to innovation, these two aspects are becoming more and more meaningful. The innovative capacity of firms does not only depend on their own research and development $(R \& D)$ capabilities. The possibility to cooperate during innovation processes with external partners such as customers, industrial suppliers, producer service firms, research institutes, and competitors becomes an important locational factor that reduces risks and uncertainties and leads to collective learning (De Bresson and Amesse 1991; Lakshmanan and Okumura 1995; Malecki and Oinas 1998).

Due to their size, metropolitan regions offer a variety of potential network partners to local firms, ensuring synergies, creating further knowledge, and resulting in technological progress. Besides these agglomeration economies, metropolitan regions are characterized by a high degree of openness. Metropolitan regions are, among others, locations of multinationals, either foreign or domestic, innovative small and medium-sized enterprises (SMEs), and research institutes that are linked to cooperation partners worldwide. 
In the case of multinationals, there is a clear tendency for utilizing several home bases instead of one headquarter. That means that multinationals establish a global network of production plants and R\&D centers that are closely interrelated. As a consequence, multinationals in a metropolitan region are in a constant exchange of ideas and experiences with outside cooperation partners. Innovative SMEs, for example, in biotechnology or telecommunication, have to cooperate internationally. The complexity of innovation processes in these two branches forces local firms to gain immediate access to leading firms and research institutes. Research institutes themselves are very much engaged in international cooperation projects and connected to international science networks.

Besides this general discussion, there are no studies analyzing the importance of metropolitan innovation systems with a rigid methodology comparing different metropolitan regions with each other. Using data from the European Regional Innovation Survey, a comparison between the metropolitan innovation systems of Barcelona, Stockholm, and Vienna is provided in this article with the aim to shed some light onto how innovative actors cooperate within metropolitan innovation systems.

In the next section, I will briefly summarize the literature on national and regional innovation systems, introducing metropolitan innovation systems as a specific form of a regional innovation system. The third section describes the methodological approach to analyzing the firms' innovation and cooperation behavior and the used database. The fourth section compares the three metropolitan regions in the European context using official statistics. The results of the innovative performance of manufacturing firms in the three metropolitan innovation systems are presented in the fifth section. Acknowledging the growing importance of innovation networks, the sixth section demonstrates the external relationships of manufacturing firms, producer service firms, and research institutes. The final section summarizes the results under the light of reorienting regional policy toward innovation stimulation. The results show that even between metropolitan regions, profound differences in innovation activities exist. Only in Stockholm is a close interrelationship between the science and the business sector observed, resulting in higher innovation inputs and outputs.

\section{From NATIONAL TO METROPOLITAN SYSTEMS OF INNOVATION}

Since the mid-1980s, research about innovation processes is increasingly directed to the analysis of national systems of innovation (Freeman and Soete 1997). The systems of innovation concept interprets innovation as a systemic and complex process, which is not seen as a linear sequence as in the neoclassical view and does not depend on one single entrepreneur's decisions. Instead, it is accepted that innovation is a result of intensive interactions between different actors within and outside a firm and therefore depends heavily on relationships between the firm and its environment. The business environment influences the firm's innovation activities in two ways. On one hand, innovative firms seek the cooperation of other 
actors to access information, knowledge, and other resources; to exchange experiences; and to find jointly adequate solutions. Potential cooperation partners are other firms, for example, customers, suppliers, competitors, service providers, and/or research institutes, financial institutions, political decision makers, and so on. On the other hand, the business environment, which can change in the course of time, determines the firm's activities. The social and cultural embeddedness, the institutional and regulatory framework, and the existing infrastructure influence entrepreneurial decisions. In this broad sense, innovation is the outcome of an interplay between different actors, whose actions are determined by their environment (Camagni 1991; Crevoisier 1998; Hudson 1999).

A comprehensive analysis of innovation processes has to include numerous factors. In Edquist's (1997) opinion, the concept of innovation systems is the only framework in which innovation processes can be examined:

If we want to describe, understand, explain — and perhaps influence-processes of innovation, we must take all important factors shaping and influencing innovations into account. The system of innovation approach — in its various forms-is designed to do this. Attempts to understand the structure and dynamics of such systems are at the core of modern thinking about innovation processes. (P. 4)

According to Lundvall (1992), a national innovation system includes "all parts and aspects of the economic structure and the institutional set-up affecting learning as well as searching and exploring the production system, the marketing system and the system of finance" (p. 12).

Whereas Lundvall (1992) and Nelson (1993) concentrated their analyses on the nation-state, increasing attention has been paid to the regional level since the mid-1990s. The recent discussion stresses two aspects (Fischer et al. 2001):

- Developed countries need, to maintain their international competitiveness, innovative and dynamic firms. These firms tend to be concentrated in certain regions where they can find a favorable business environment.

- Innovative firms succeed in linking local with national or even global knowledge sources. They are able to generate new ideas by using their own and external expertise and to transform them into marketable products.

The stronger emphasis on the regional and local level led to a fairly high number of studies about regional innovation systems (e.g., Cooke and Morgan 1998; Braczyk, Cooke, and Heidenreich 1998; Maskell et al. 1998). Again, their point of departure is the chain-linked innovation model that emphasizes feedback loops and interactions between different actors during innovation processes. The authors transferred the systemic elements of a national innovation system to the regional level. In short, they argued that region-specific conditions and cooperative relationships between different actors influence the regional innovation potential either positively or negatively. They concluded that "regions which possess the full pano- 
ply of innovation organizations set in an institutional milieu where systemic linkage and interactive communication among the innovation actors is normal, approach the designation of regional innovation systems" (Cooke and Morgan 1998, 71). It would be wrong to interpret regional innovation systems as being isolated from the national and/or international context. The national scale continues to be crucial in setting important framework conditions like laws and investment (e.g., in research and education). The international scale gives important impulses about potential markets and the development of new products; it also provides knowledge from outside the region (Revilla Diez 2000).

Recent studies about the spatial distribution of innovation activities show that metropolitan regions have a high innovation potential (e.g., BMBF 2000 and Beise and Stahl 1999 for Germany; Brouwer, Budil-Nadvornikova, and Kleinknecht 1999 for the Netherlands; Varga 1998 and Anselin, Varga, and Acs 1997 for the United States). For example, Audretsch and Feldman (1999) proved empirically that cities and especially metropolitan regions are the most important locations for innovations. Ninety-six percent of all registered product innovations were generated in metropolitan regions. Furthermore, Audretsch and Feldman (1999) presented empirical evidence for Jane Jacobs's (1969) argument that diversity fosters innovation. They found that sectoral specialization on a small number of branches has a negative effect on the regional innovation output level. Metropolitan regions that generally are characterized by a diverse economic structure achieve significantly higher innovation outputs (Audretsch and Feldman 1999). These results underline the fact that metropolitan regions offer favorable conditions for innovative firms. Here, these firms find a diversified industrial structure, qualified work force, capable cooperation partners in business (customers, suppliers, competitors, producer services), and research institutes (Suarez-Villa and Fischer 1995; Howells 1983; Ewers and Wettmann 1980). But contrary to this argumentation, Acs, FritzRoy, and Smith (2001) have shown empirical evidence for the benefits of specialization. However, metropolitan regions tend to be the driving forces in national and global innovation processes (Shefer and Frenkel 1998).

The uneven spatial distribution of innovations demonstrates that metropolitan regions are very important in respect to the generation of new ideas, further development of technological progress, and knowledge-based regional and national development. Metropolitan regions offer firms spatial, technological, and institutional proximity and specific resources whose exploitation generates significant externalities (Fischer et al. 2001).

For these reasons, metropolitan regions can be interpreted as metropolitan innovation systems. Technology-oriented firms need to find innovative solutions a minimum of locational advantages that can only be found in metropolitan innovation systems. Of central importance is the availability of cooperation partners not only within but also outside the metropolitan innovation system (Davelaar and Nijkamp 1989; Harrison, Kelley, and Gant 1996). Some examples are industrial suppliers and customers, producer service firms, and research institutes. The full exploitation 
of technological opportunities requires a satisfactory division of labor between small and large enterprises as well as the coexistence of many different kinds of producers and service providers. Research institutes fulfill at least two important roles. The first refers to the training of a qualified work force and the second to the generation and diffusion of knowledge (Fischer et al. 2001; Charles and Goddard 1997; Fritsch et al. 1998; Acs, Audretsch, and Feldman 1991, 1994).

On the basis of this short theoretical discussion, the empirical analysis is directed to the following questions:

1. How does the innovation capacity and performance across the metropolitan innovation systems surveyed differ in comparison to other regions in the European Union (EU)?

2. How different is the innovative capacity of the manufacturing firms across the metropolitan innovation systems surveyed?

3. How important is external cooperation for manufacturing firms, producer services, and research institutes and to what extent does spatial proximity matter for cooperation networks?

4. What is the role of producer service firms within metropolitan innovation systems? Do they differ in their own R\&D capacities and in the way in which they support manufacturing firms' innovation activities across the case study regions?

5. How important are research institutes for businesses within metropolitan innovation systems?

\section{METHOD: THE EUROPEAN REGIONAL INNOVATION SURVEY}

Since the 1970s, numerous innovation and network studies were conducted on a national and regional scale; however, a basic problem is their lacking comparability. All of these studies present interesting insights into innovation processes, and their different focus on product or process innovation on sectors (all sectors vs. high-tech sectors), firm size (small and medium-sized firms vs. large firms), geographic orientation (regional vs. national), theoretical assumptions (linear vs. chain-linked innovation model), and methodology (case study approach vs. postal survey) limit their transferabilty. The European Regional Innovation Survey (ERIS) is a comprehensive and integrated attempt to overcome these shortcomings. The database was elaborated within the framework of the extensive research program "Technological Change and Regional Development in Europe" funded by the German Research Association. In a joint project between the University of Hannover, the University of Cologne, the Technical University of Freiberg, and the Fraunhofer Institute for System Analysis, postal surveys were conducted in eleven regions across Europe. Written questionnaires were sent to the most important actors in regional innovation systems-manufacturing firms, producer services, and research institutions - to analyze their innovative and networking activities. In the case of the manufacturing survey, firms belonging to manufacturing sectors 15-36 according to the EU classification of economic activities (NACE) were selected. The producer service survey covers producer service firms in computer 
TABLE 1. Metropolitan Innovation Survey

\begin{tabular}{lrrr}
\hline \hline & \multicolumn{3}{c}{ Metropolitan Innovation System } \\
\cline { 2 - 4 } Survey Subject & Barcelona & Stockholm & Vienna \\
\hline Manufacturing firms & 394 & & \\
$\quad$ Responding firms & 15 & 24 & 204 \\
$\quad$ Representativeness ratio (\%) & & 334 & 23 \\
Producer service firms & 105 & 26 & 185 \\
$\quad$ Responding firms & 18 & 173 & 29 \\
$\quad$ Representativeness ratio (\%) & 148 & 50 & 290 \\
Research institutes & 35 & & 45 \\
$\quad$ Responding research units & & & \\
$\quad$ Representativeness ratio (\%) & &
\end{tabular}

Source: European Regional Innovation Survey.

software (hardware consultancy, software consultancy, and supply, data processing, database activities, NACE 72.1-72.4), technical consultancy (architectural, engineering, and related technical consultancy and technical testing and analysis, NACE 74.2, 74.3), business consultancy (business and management consultancy, NACE 74.14), and market research and advertising (market research and public opinion polling, advertising, activities of trade fairs, exhibitions, and congress organizers, NACE 74.13, 74.4, 74.8). The research institutes survey was addressed to the science fields of architecture, construction, surveying, biology, chemistry, medicine, mathematics, informatics, physics, electrotechnology, mechanical engineering, economics, social and geo-sciences. To obtain a detailed insight into the research and network activities of the research institutions (i.e., universities and other research institutions), the questionnaire was sent to the departmental level, or, if these units were too large, to the level of research groups.

Basically, the same actor-specific questionnaires were used in all the regions surveyed, guaranteeing a high degree of comparability (Fritsch et al. 1998). This article focuses on the results from three metropolitan regions: Barcelona, Stockholm, and Vienna. The data were collected jointly with the professors Dr. Folke Snickars, Royal Institute of Technology in Stockholm; Dr. Manfred Fischer, Vienna University of Economics and Business Administration; and Dr. Pere Escorsa, Polytechnical University of Catalonia. The three regions were defined in a functional perspective. In addition to the city core area, where mainly producer services and research institutions are located, the industrial hinterland is included. The metropolitan region of Barcelona comprises the communities of Barcelona, Baix Llobregat, Valles Occidental, Valles Oriental, and Maresme. The metropolitan region of Stockholm comprises the province of Stockholm, Uppsala, Södermanslands, Örebro, and Vastmanlands. The metropolitan region of Vienna comprises the city of Vienna and the districts Baden, Bruck an der Leitha, Gänserndorf, Korneuburg, Mödling, Tulln, and Vienna Umgebung. Table 1 gives an overview on 
sample sizes and response patterns. Overall, the survey data in the metropolitan regions surveyed are a good representation of the total population.

\section{The Metropolitan InNOVATION SyStems OF BARCELONA, STOCKHOLM, AND VIENNA IN THE EUROPEAN CONTEXT}

The three metropolitan innovation systems surveyed vary significantly in their innovative capabilities. However, these differences are already clear when one compares the national innovation systems. Table 2 summarizes the strengths and weaknesses of the three national innovation systems. With respect to innovation, Sweden is the most successful country. Sweden reaches the top position in the EU with respect to the gross expenditure in R\&D and number of researchers per 1,000 labor force. The private sector is the driving force within the national R\&D system. Nearly 68 percent of all expenses in R\&D come from the business sector. As a result, the Swedish patent applications at the European Patent Office are twice as high as the European average. Interestingly, in Sweden foreign ownership of domestic inventions is lower than in Austria and Spain, but at the same time Swedish ownership of inventions made abroad is markedly higher than in the two other countries. This shows, on one hand, that the Swedish R\&D system has a solid base within the country but, on the other hand, that Swedish multinationals are highly competitive in an international perspective and able to control inventions outside the country.

With respect to innovation indicators, Austria follows second. Although it achieves one of the highest per capita incomes within the EU, its R\&D system shows several weaknesses. Not only is the input in $R \& D$, measured as the share of gross expenditure in $\mathrm{R} \& \mathrm{D}$, below the EU average, but the active participation of the business sector in R\&D activities is also very limited. Contrary to Sweden, the public R\&D system plays a leading role in the innovation system. The high proportion of foreign ownership of domestic inventions demonstrates the attractiveness of Austrian research capacities for multinationals. But, at the same time, it illustrates the heavy dependence of the Austrian innovation system on foreign $R \& D$ efforts. Austrian firms are not able to control inventions abroad in a substantial manner. As a whole, the Austrian R\&D system is not able to achieve high innovative outputs. The patent indicator clearly underlines the weak position in international standards.

The Spanish innovation system clearly lags behind the two other countries. The Spanish economy has been able to achieve high economic growth rates since its membership in the European Community (EC). This catching-up process, among other factors, was heavily based on foreign investment. But Spain is still not reaching the EU average in terms of per capita income. In comparison to Sweden, which can be labeled as an inventor country, the Spanish economy is much more an applier of new knowledge, whereas Austria lies in between. The Spanish indicators on $R \& D$ expenditure lay significantly below the EU average. Like the Austrian case, the participation of businesses in R\&D is rather low, resulting in a high proportion 
TABLE 2. National Innovation System in Comparison

\begin{tabular}{|c|c|c|c|c|c|c|c|}
\hline Country & $\begin{array}{c}\text { GDP per } \\
\text { Head of } \\
\text { Population (\% } \\
\text { of U.S.) } 1997\end{array}$ & $\begin{array}{c}\text { Gross } \\
\text { Domestic } \\
\text { Expenditure } \\
\text { on } R \& D \text { as } \\
\text { a\% of GDP }\end{array}$ & $\begin{array}{c}\text { Researchers } \\
\text { per 10,000 } \\
\text { Labor } \\
\text { Force }\end{array}$ & $\begin{array}{c}R \& D \\
\text { Expenditure } \\
\text { by Business } \\
\text { Enterprises in \% } \\
\text { of All Funds } 1997\end{array}$ & $\begin{array}{c}\text { Patent } \\
\text { Applications at } \\
\text { EPO per Head } \\
\text { of Population } \\
1996\end{array}$ & $\begin{array}{c}\text { Foreign } \\
\text { Ownership of } \\
\text { Domestic } \\
\text { Inventions }^{\mathrm{a}} \\
\text { 1993-95 }\end{array}$ & $\begin{array}{l}\text { Domestic } \\
\text { Ownership of } \\
\text { Foreign }^{\text {thentions }} \\
\text { Inven }^{\text {1993-95 }}\end{array}$ \\
\hline Sweden & 70 & 3.9 & 86 (1997) & 67.7 & 187 & 10.0 & 10.4 \\
\hline Austria & 79 & 1.5 & 34 (1993) & 49.3 & 95 & 20.9 & 8.2 \\
\hline Spain & 55 & 0.9 & 33 (1997) & 44.7 & 11 & 16.6 & 4.1 \\
\hline Germany & 75 & 2.3 & 59 (1995) & 61.6 & 186 & 6.9 & 4.6 \\
\hline United Kingdom & 70 & 1.9 & $51(1996)$ & 49.5 & 69 & 23.0 & 11.3 \\
\hline France & 73 & 2.2 & $61(1996)$ & 48.5 & 95 & 8.9 & 5.8 \\
\hline United States & 100 & 2.7 & 74 (1993) & 64.3 & 78 & 5.0 & 8.8 \\
\hline Japan & 84 & 2.9 & 92 (1997) & 73.4 & 103 & 3.0 & 1.8 \\
\hline \multicolumn{8}{|l|}{ Organization for Economic } \\
\hline Cooperation and Deveopement & 75 & 2.2 & $55(1995)$ & 62.3 & & 8.2 & 8.1 \\
\hline European Union & 70 & 1.8 & $50(1996)$ & 52.8 & 94 & 6.5 & 3.5 \\
\hline
\end{tabular}

Source: Eurostat (1999) and the Organization for Economic Cooperation and Development (1999).

Note: $\mathrm{GDP}=$ gross domestic product; $\mathrm{R} \& \mathrm{D}=$ research and development; $\mathrm{EPO}=$ European Patent Office

a. Share of patent applications to the EPO owned by foreign residents in total patents invented domestically.

b. Share of patent applications to the EPO invented abroad in total patents owned by country residents. 
of foreign ownership of domestic inventions. Using patent data, the distance from the knowledge- and technology-intensive economies is even bigger.

The differences revealed on the national level continue to be present on the regional level (see Table 3). The metropolitan innovation system of Stockholm seems to be much more innovative than the metropolitan innovation systems in Vienna and Barcelona. The strengths of the Stockholm innovation system can be seen in the high number of patent applications at the European Patent Office. One explanation could be the expenses in $R \& D$, which are two times higher than in Vienna or Barcelona. Another explanation can be derived from the much higher qualification levels of the population in the metropolitan region of Stockholm. Thirty-eight percent of the population aged twenty-five to sixty-four have completed a university-level education. As a consequence, the business enterprise scientists and researchers are relatively much more numerous in Stockholm than in Vienna and Barcelona.

The metropolitan system of Vienna follows in term of innovativeness. The per capita income is significantly higher than in the two other metropolises. But the R\&D output measured in patent applications demonstrates that the former knowledge center in Europe has declined in importance. The weak contribution of the private business sector to the metropolitan innovation system is expressed in low business expenditures in R\&D. Surprisingly, the proportion of highly qualified work force is even lower than in the metropolitan region of Barcelona.

The metropolitan system of Barcelona is the leading Spanish region in business $\mathrm{R} \& \mathrm{D}$, but in the international perspective this position has to be relativized. The region was quite successful in attracting foreign investments and in achieving high economic growth after the Spanish entry to the EC in 1986. In only ten years, the region succeeded in reaching the European average in per capita income. The innovative output measured in patents is still far behind the leading European regions, comparable to the output of the Vienna metropolitan system. The greatest factor impeding a higher innovative performance is the weak business sector. But the efforts toward improving the higher education system seem to be paying off. The proportion of university-level qualified work force is already higher than in Vienna.

\section{INNOVATION PERFORMANCE OF MANUFACTURING FIRMS}

The differences observed so far with the help of official statistics are confirmed by the ERIS. The innovation capacity of the manufacturing firms surveyed differs significantly between the three metropolitan innovation systems. Differences not only across industrial branches but also within the branches are notable (see Table 4). The innovation performance of manufacturing firms was measured by input and output indicators. When input indicators like the R\&D personnel and the $R \& D$ expenditure ratio are analyzed, the manufacturing firms in the metropolitan regions of Vienna and Stockholm realize much higher R\&D inputs than the firms in the metropolitan region of Barcelona. The differences become very clear in the case 
TABLE 3. Metropolitan Innovation Systems in Comparison

\begin{tabular}{|c|c|c|c|c|c|c|c|}
\hline & $\begin{array}{l}\text { Barcelona- } \\
\text { Catalonia }\end{array}$ & Stockholm & Vienna & Oberbayern & $\begin{array}{l}\text { Île-de- } \\
\text { France }\end{array}$ & $\begin{array}{l}\text { Greater } \\
\text { London }\end{array}$ & $\begin{array}{l}\text { European } \\
\text { Union }\end{array}$ \\
\hline Gross domestic product per capita $(E U=100) 1996$ & 99 & 123 & 167 & 157 & 160 & 140 & 100 \\
\hline Unemployment rate (\%) 1997 & 17.4 & 7.9 & 5.9 & 4.8 & 10.7 & 9.7 & 10.7 \\
\hline \multicolumn{8}{|l|}{$\begin{array}{l}\text { Educational level of the population aged twenty-five } \\
\text { to fifty-nine (total \%) }\end{array}$} \\
\hline Low & 63 & 17 & 22 & 20 & 34 & 45 & 41 \\
\hline Medium & 17 & 45 & 63 & 52 & 38 & 24 & 40 \\
\hline High & 19 & 38 & 15 & 27 & 29 & 31 & 20 \\
\hline Number of patents, European Patent Office 1995 & 136 & 522 & 162 & 1,339 & 2,222 & 242 & 33,651 \\
\hline
\end{tabular}

Source: Eurostat (1999). 
of high-tech sectors, reflecting the backwardness of the metropolis in southern Europe. In all three regions, the highest R\&D personnel ratio can be found in the sector of electrical and optical equipment. But again, the Barcelonese figure is less than half as high as in the two other regions. With respect to R\&D expenditure ratio, the picture across the regions is more diffuse. In the metropolitan region of Barcelona, the food industry is the most R\&D-intensive sector. The food sector in Barcelona is one of the few sectors in which domestic firms reach international competitiveness by their own R\&D capabilities and strategies. In Stockholm, the industrial sector of machinery and transport equipment—one of the major industrial sectors of the Stockholm economy-and in Vienna, the sector of electrical and optical equipment are the most $R \& D$ intensive in terms of $R \& D$ expenditure. Besides these branch differences, the size of the manufacturing firms influences the R\&D input levels. Whereas in the metropolitan systems of Stockholm and Vienna large firms with more than five hundred employees reach the highest R\&D input levels, in Barcelona it is the small and medium-sized firm with fewer than one hundred employees. The relatively poor commitment of large firms in Barcelona to R\&D is a consequence of the low number of domestic multinationals. The number of multinational headquarters is distinctly higher in Stockholm and Vienna.

The overall innovation capacity of the manufacturing firms has also to be discussed as well in terms of output indicators such as the innovation rate or the share of turnover by product innovations (see Table 5). Contrary to the results obtained so far, the manufacturing firms in Barcelona achieve the highest number of new product developments, followed by Stockholm and Vienna. With respect to the share of turnover by product innovations, the metropolitan region of Vienna becomes the most innovative, followed by Barcelona and then Stockholm. The relatively good results for Vienna and Barcelona are the consequence of the initiated catching-up process. In the past decades, as shown earlier, these two regions did not belong to the most innovative regions in Europe. The increased competition since their membership in the EU has forced the firms to invest more in R\&D to improve product quality and to develop new products.

\section{The Role of EXTERnAl CoOPERATION AND SPATIAL PROXIMITY}

\section{MANUFACTURING FIRMS' COOPERATION NETWORKS}

The two most important research goals of the empirical surveys in the three metropolitan regions were to detect on a representative level the importance of external cooperation in innovation processes and the role of spatial proximity for such innovation cooperation. The network paradigm postulated by Cooke and Morgan in 1993 implies that networks link innovation actors, resources, and activities in and between innovation systems, enabling the exchange of information and knowledge and facilitating learning processes. Overall, manufacturing firms in all the regions 
TABLE 4. Selected Research and Development (R\&D) Characteristics of Surveyed Firms in Manufacturing (1994-1996)

\begin{tabular}{|c|c|c|c|c|c|c|}
\hline & \multicolumn{2}{|c|}{ Barcelona } & \multicolumn{2}{|c|}{ Stockholm } & \multicolumn{2}{|c|}{ Vienna } \\
\hline & $\begin{array}{c}R \& D \\
\text { Personnel Ratio }\end{array}$ & $\begin{array}{c}R \& D \\
\text { Expenditure Ratio }\end{array}$ & $\begin{array}{c}R \& D \\
\text { Personnel Ratio }\end{array}$ & $\begin{array}{c}R \& D \\
\text { Expenditure Ratio }\end{array}$ & $\begin{array}{c}R \& D \\
\text { Personnel Ratio }^{\mathrm{a}}\end{array}$ & $\begin{array}{c}R \& D \\
\text { Expenditure Ratio }\end{array}$ \\
\hline \multicolumn{7}{|l|}{ Industrial sector } \\
\hline Textiles and clothing & 60.6 & 4.12 & 52.6 & 10.0 & 19.8 & 5.79 \\
\hline Food industry & 17.0 & 9.68 & 25.4 & 0.9 & 27.7 & 1.75 \\
\hline Wood, paper, and printing & 15.8 & 0.75 & 54.1 & 2.5 & 9.2 & 1.55 \\
\hline Chemicals & 76.1 & 4.48 & 70.2 & 4.3 & 48.3 & 6.53 \\
\hline Electrical and optical equipment & 107.1 & 4.69 & 144.0 & 9.5 & 255.3 & 16.03 \\
\hline Basic metals and metal products & 54.3 & 4.21 & 31.8 & 2.8 & 29.2 & 2.37 \\
\hline Machinery and transport & 67.5 & 3.98 & 117.1 & 14.1 & 30.5 & 5.52 \\
\hline High technology & 74.0 & 4.2 & 119.0 & 9.2 & 132.9 & 10.58 \\
\hline \multicolumn{7}{|l|}{ Employment size } \\
\hline$\leq 49$ & 70.9 & 5.87 & 86.9 & 4.4 & 56.5 & 2.79 \\
\hline $50-99$ & 78.1 & 4.98 & 85.9 & 5.9 & 31.6 & 3.15 \\
\hline $100-499$ & 33.6 & 2.24 & 68.8 & 3.8 & 35.3 & 4.28 \\
\hline$\geq 500$ & 63.9 & 4.57 & 92.0 & 12.5 & 127.2 & 10.30 \\
\hline Total & 61.8 & 4.3 & 84.0 & 7.1 & 96.0 & 8.2 \\
\hline
\end{tabular}

Source: European Regional Innovation Survey.

a. Per 1,000 employees. 
TABLE 5. Innovation Activities of Surveyed Firms (1994-1996)

\begin{tabular}{|c|c|c|c|c|c|c|}
\hline & \multicolumn{2}{|c|}{ Barcelona } & \multicolumn{2}{|c|}{ Stockholm } & \multicolumn{2}{|c|}{ Vienna } \\
\hline & $\begin{array}{c}\text { Innovation } \\
\text { Rate }^{\mathrm{a}}\end{array}$ & $\begin{array}{l}\text { Share of Turnover } \\
\text { by Product } \\
\text { Innovations }\end{array}$ & $\begin{array}{c}\text { Innovation } \\
\text { Rate }^{\mathrm{a}}\end{array}$ & $\begin{array}{c}\text { Share of Turnover } \\
\text { by Product } \\
\text { Innovations }\end{array}$ & $\begin{array}{c}\text { Innovation } \\
\text { Rate }^{\mathrm{a}}\end{array}$ & $\begin{array}{l}\text { Share of Turnover } \\
\text { by Product } \\
\text { Innovations }\end{array}$ \\
\hline \multicolumn{7}{|l|}{ Industrial sector } \\
\hline Textiles and clothing & 99.4 & 0.47 & 340.9 & 0.68 & 65.8 & 0.13 \\
\hline Food industry & 13.2 & 0.07 & 22.9 & 0.11 & 33.7 & 0.28 \\
\hline Wood, paper, and printing & 129.6 & 0.15 & 62.6 & 0.20 & 19.3 & 0.04 \\
\hline Chemicals & 73.4 & 0.15 & 37.7 & 0.06 & 36.8 & 0.19 \\
\hline Electrical and optical equipment & 139.6 & 0.33 & 36.3 & 0.45 & 6.4 & 0.51 \\
\hline Basic metals and metal products & 130.9 & 0.20 & 28.0 & 0.13 & 12.0 & 0.57 \\
\hline Machinery and transport & 6.9 & 0.47 & 23.6 & 0.38 & 4.3 & 0.53 \\
\hline High technology & 34.1 & 0.37 & 29.4 & 0.26 & 12.8 & 0.43 \\
\hline \multicolumn{7}{|l|}{ Employment size } \\
\hline$\leq 49$ & 176.2 & 0.22 & 170.6 & 0.24 & 134.9 & 0.13 \\
\hline $50-99$ & 106.4 & 0.29 & 54.8 & 0.31 & 86.5 & 0.16 \\
\hline $100-499$ & 77.0 & 0.22 & 20.8 & 0.11 & 6.5 & 0.35 \\
\hline$\geq 500$ & 4.0 & 0.37 & 10.7 & 0.34 & 2.3 & 0.45 \\
\hline Total & 49.4 & 0.33 & 30.0 & 0.22 & 15.2 & 0.43 \\
\hline
\end{tabular}

Source: European Regional Innovation Survey.

a. Denotes number of new products per 1,000 employees. 
TABLE 6. Cooperation Partners of Innovating Manufacturing Firms

\begin{tabular}{lccc}
\hline \hline & Barcelona & Stockholm & Vienna \\
\hline $\begin{array}{l}\text { Cooperating manufacturing firms } \\
\text { Cooperation partners of manufacturing firms }\end{array}$ & 78 & 64 & 63 \\
Customer & 69 & 75 & 52 \\
Supplier & 56 & 37 & 37 \\
Producer services & 61 & 45 & 60 \\
Competitors & 23 & 18 & 23 \\
Research institutes & 23 & 34 & 23 \\
\hline
\end{tabular}

Source: European Regional Innovation Survey.

a. In percentage of all firms.

b. In percentage of all cooperating manufacturing firms.

surveyed are strongly engaged in innovation networking. Firms' innovative activity is not solely based on in-house capabilities. The results obtained clearly demonstrate the importance of external cooperation in the innovation process of manufacturing and producer service firms (see Table 6). Interestingly, the most important cooperation partners for manufacturing firms are customers, suppliers, and producer service firms. For the producer service firms surveyed, industrial customers and other producer service firms are the major cooperation partner. Vertical cooperation partners along the value chain are much more involved in innovation networks than horizontal cooperation partners like research institutes and competitors. The spatial range of networking varies between vertical and horizontal cooperation partners. Spatial proximity is much more important in horizontal linkages between manufacturing firms and research institutes or competitors, whereas cooperation with vertical cooperation partners is realized over larger distances. It can be stated that the network pattern of the manufacturing firms is much more complex than expected. Spatial proximity of cooperation partners and cooperation partners at larger distances are a common picture of the firms surveyed. This reflects the need to make use of local but at the same time national or even international knowledge sources.

But against this general picture, differences depending on the size, industry sector, and innovativeness of firms are significant. Small manufacturing firms tend to be less engaged in innovation networks than large firms. Manufacturing firms showing a high innovative performance are strongly connected to cooperation partners than less innovative ones. With respect to branches, the results underline the importance of external cooperation for technology- and knowledge-intensive industries, which also cooperate more often with horizontal cooperation partners than the low-tech industries.

Between the three metropolitan innovation systems, differences in the external cooperation of the manufacturing firms can be distinguished. The metropolitan region of Barcelona reaches the highest percentage of networking manufacturing 
TABLE 7. Geographical Distribution of Cooperation Partners (percentage of cooperating firms)

\begin{tabular}{|c|c|c|c|c|c|c|c|c|c|c|c|c|}
\hline \multirow[b]{3}{*}{ Level } & \multicolumn{4}{|c|}{ Barcelona } & \multicolumn{4}{|c|}{ Stockholm } & \multicolumn{4}{|c|}{ Vienna } \\
\hline & \multirow[t]{2}{*}{$M A$} & \multicolumn{2}{|c|}{$P S$} & \multirow[t]{2}{*}{$\overline{R I}$} & \multirow[t]{2}{*}{$\overline{M A}$} & \multicolumn{2}{|c|}{$P S$} & \multirow[t]{2}{*}{$R I$} & \multirow[t]{2}{*}{$M I$} & \multicolumn{2}{|c|}{$P S$} & \multirow[t]{2}{*}{$R I$} \\
\hline & & $M A$ & $R I$ & & & $M A$ & $R I$ & & & $M A$ & $R I$ & \\
\hline Metropolitan & 38 & 33 & 46 & 30 & 32 & 32 & 31 & 23 & 32 & 34 & 48 & 27 \\
\hline National & 32 & 45 & 22 & 40 & 43 & 43 & 42 & 43 & 22 & 30 & 24 & 23 \\
\hline International & 30 & 22 & 32 & 30 & 25 & 25 & 27 & 34 & 46 & 36 & 28 & 50 \\
\hline Total & 100 & 100 & 100 & 100 & 100 & 100 & 100 & 100 & 100 & 100 & 100 & 100 \\
\hline
\end{tabular}

Source: European Regional Innovation Survey.

Note: $\mathrm{MA}=$ manufacturing firms; PS = producer service firms (the geographic distribution of cooperation partners is distinguished between manufacturing firms and research institutes); RI $=$ research institutes.

firms, followed by the metropolitan region of Stockholm and Vienna. The high share of Barcelona can be explained by two factors: (1) the large importance of small and medium-sized firms, which have a long tradition of interacting among themselves, and (2) the presence of multinationals having a frequent exchange with their headquarters and other research and production sites worldwide. The percentages of cooperating manufacturing firms in the more mature (in economic terms) metropolitan regions of Stockholm and Vienna are quite similar. The lower percentage of networking firms may be an indication of a lesser need to cooperate due to better in-house R\&D capabilities.

The importance of spatial proximity in innovation networks with respect to metropolitan innovation systems is directly linked to two questions. The first question is whether the innovative firms make use of the local knowledge sources by cooperating with different actors in the region so that the metropolitan region can be regarded as a breeding place for innovations, and the second question is whether metropolitan regions fulfill a bridging function between the local and national economy and between the internationally most competitive regions in the world. As discussed in the introduction, metropolitan regions are increasingly seen as global, national, and regional development engines. The importance of the metropolitan regions of Barcelona, Vienna, and Stockholm for the national and regional economies is undoubtedly high.

To analyze the breeding and gateway function of metropolitan regions, the external cooperation links of manufacturing firms, producer service firms, and research institutes are surveyed. Table 7 shows that all three metropolitan innovation systems have a high degree of openness. Overall, the location of the cooperation partners of all the actors surveyed demonstrates that cooperation partners are almost evenly distributed over the three regional levels (metropolitan, national, and international). This indicates that the actors within a metropolitan innovation system are able to combine local with external knowledge sources, either on a national or 
international level. In contrast to this general picture, manufacturing firms in Barcelona tend to cooperate more intensively with local partners; in Stockholm, with partners at the national level; and in Vienna, with international partners. The strongest outward orientation is visible at research institutes that are linked mostly to national and international knowledge sources. Interestingly, the regional cooperation pattern of producer service firms depends heavily on the type of cooperation partner. If producer service firms cooperate with manufacturing firms, a stronger national or international orientation can be deduced. If the producer service firms cooperate with research institutes, the metropolitan level becomes more important.

THE ROLE OF PRODUCER SERVICE FIRMS

IN MANUFACTURING FIRMS' INNOVATION PROCESSES

Producer service firms play a very crucial role in supporting innovation activities in industry. In the metropolitan region of Vienna, producer service firms are the most important external cooperation partner for the manufacturing firms surveyed; in the metropolitan regions of Stockholm and Barcelona, they follow second in importance after customers. This illustrates that producer service firms take a leading position within an innovation system. Their innovative capabilities and capacities are decisive for the functioning of an innovation system, whether it is on the national, regional, or local scale. As in the case of the manufacturing firms, the innovative performance of the producer service firms surveyed was analyzed by numerous indicators (see Table 8). Again, similarities and differences across the metropolitan regions can be distinguished. When input indicators like R\&D expenditure or the R\&D personnel ratio are used, common features of the analyzed knowledge-intensive business services prevail. According to the mentioned input indicators, the two most important service sectors are the sector of computer software and of technical consultancy. In the metropolitan region of Stockholm, the sector of computer software achieves the highest R\&D inputs for both indicators. In the metropolitan region of Barcelona, the R\&D expenditure ratio is highest in computer software, and the personnel ratio is highest in technical consultancy. In the metropolitan region of Vienna, technical consultants are the most R\&D-intensive service firms. Compared to Stockholm and Barcelona, the Viennese computer software firms fall behind in terms of R\&D inputs. With respect to firm size, it can be stated that in Stockholm and Barcelona, small firms with fewer than 20 employees reach the highest input indicators. Only in Vienna is the highest personnel ratio reached by firms with 50 to 249 employees.

THE IMPORTANCE OF RESEARCH INSTITUTES, ASSISTING FIRMS' INNOVATION ACTIVITIES

Overall, it is necessary to relativize the outstanding importance of research institutes in business innovation processes that is often stated in the literature on the 
TABLE 8. Selected Research and Development (R\&D) Characteristics of Surveyed Firms in Producer Services (1994-1996)

\begin{tabular}{|c|c|c|c|c|c|c|}
\hline & \multicolumn{2}{|c|}{ Barcelona } & \multicolumn{2}{|c|}{ Stockholm } & \multicolumn{2}{|c|}{ Vienna } \\
\hline & $\begin{array}{c}R \& D \\
\text { Expenditure } \\
\text { Ratio }(\%)\end{array}$ & $\begin{array}{c}R \& D \\
\text { Personnel }^{\text {Ratio }}{ }^{\mathrm{a}}\end{array}$ & $\begin{array}{c}R \& D \\
\text { Expenditure } \\
\text { Ratio }(\%)\end{array}$ & $\begin{array}{c}R \& D \\
\text { Personnel }^{\text {Ratio }}{ }^{\mathrm{a}}\end{array}$ & $\begin{array}{c}R \& D \\
\text { Expenditure } \\
\text { Ratio }(\%)\end{array}$ & $\begin{array}{c}R \& D \\
\text { Personnel } \\
\text { Ratio }^{\mathrm{a}}\end{array}$ \\
\hline \multicolumn{7}{|l|}{ Service sector } \\
\hline Computer software & 9.7 & 15.0 & 5.7 & 23.7 & 4.3 & 11.2 \\
\hline Technical consultancy & 4.2 & 17.2 & 4.9 & 6.1 & 5.4 & 25.4 \\
\hline Business consultancy & 6.0 & 12.6 & 2.5 & 17.8 & 3.1 & 4.0 \\
\hline Market research and advertising & 2.5 & 6.5 & 4.7 & 20.4 & 3.7 & 8.0 \\
\hline \multicolumn{7}{|l|}{ Employment size } \\
\hline$\leq 19$ & 10.3 & 24.4 & 7.4 & 24.6 & 5.0 & 15.3 \\
\hline $20-49$ & 6.1 & 28.0 & 2.3 & 16.3 & 3.1 & 13.6 \\
\hline $50-249$ & 4.1 & 3.7 & 5.6 & 16.0 & 3.9 & 20.9 \\
\hline$\geq 250$ & 1.7 & 10.8 & 4.8 & 13.0 & 5.0 & 3.8 \\
\hline Total & 7.7 & 10.8 & 4.7 & 15.4 & 3.6 & 12.3 \\
\hline
\end{tabular}

Source: European Regional Innovation Survey.

a. Per 1,000 employees. 
TABLE 9. Cooperation of Research Institutes with Firms

\begin{tabular}{|c|c|c|c|}
\hline & Barcelona & Stockholm & Vienno \\
\hline Cooperation with firms (\%) & 71 & 64 & 55 \\
\hline \multicolumn{4}{|l|}{ Employment size of firms ${ }^{a}$} \\
\hline$\leq 49$ & 28 & 3 & 20 \\
\hline $50-99$ & 27 & 15 & 15 \\
\hline $100-499$ & 20 & 24 & 19 \\
\hline$\geq 500$ & 25 & 58 & 46 \\
\hline Total & 100 & 100 & 100 \\
\hline
\end{tabular}

Source: European Regional Innovation Survey.

a. Size distribution of firms cooperating with research institutes in percentages.

subject (Revilla Diez 2000). The results of the survey clearly showed that vertical cooperation partners, such as buyers and suppliers, and producer service firms hold a higher status in the support of business innovation processes than research institutes do. In addition, the survey impressively proves that in contrast to the hypothesis, as far as business cooperation partners are concerned, it is above all the medium-size and large firms that are the favored cooperating partners. Small businesses are not reached by the research institutes. If manufacturing firms cooperate with research institutes, they demonstrate a higher preference for neighboring institutions. Research institutes themselves cooperate intensively on a national and international scale. The active participation in international science networks allows them to fulfill the gateway function. Through their contacts, they are able to diffuse internationally available information and knowledge to local firms.

Despite this general picture, differences across the three metropolitan innovation systems are profound. In contrast to Vienna and Barcelona, manufacturing firms in Stockholm make use of research institutes in a significant way (see Table 9). Large manufacturing firms with more than five hundred employees were the most important cooperation partners for the Stockholm research institutes. In Vienna, the large manufacturers are the preferred cooperation partners of research institutes. Only in Barcelona do research institutes cooperate intensively with small manufacturing firms with fewer than one hundred employees. Taking into consideration the high number of large multinationals in Barcelona, this result shows that local research units are not able to provide knowledge resources to these global players. In other words, the most important factor for locating in Barcelona is not the knowledge base found in local research institutes.

One reason for the lower participation of research institutes in innovation networks could be the mismatch of technology fields. In Table 10, it can be clearly seen that the specialization patterns of manufacturing firms and research institutes vary significantly. The research institutes have patterns of specialization that allow one to expect only few complementary effects for local businesses, and vice versa. But interestingly, the mismatch is highest in the Stockholm metropolitan innovation 
TABLE 10. Relevance of Technology Fields for Innovations in Research Institutes and in Manufacturing Firms

\begin{tabular}{|c|c|c|c|c|c|c|}
\hline \multirow[b]{2}{*}{ Technology Field ${ }^{\mathrm{a}}$} & \multicolumn{2}{|c|}{ Barcelona } & \multicolumn{2}{|c|}{ Stockholm } & \multicolumn{2}{|c|}{ Vienna } \\
\hline & $R I^{\mathrm{b}}$ & $M A N U^{\mathrm{c}}$ & $R I^{\mathrm{b}}$ & $M A N U^{\mathrm{c}}$ & $R I^{\mathrm{b}}$ & $M A N U^{\mathrm{c}}$ \\
\hline Biotechnology & 15 & 11 & 31 & 9 & 18 & 14 \\
\hline Chemistry & 18 & 31 & 19 & 24 & 12 & 23 \\
\hline Power engineering & 10 & 14 & 19 & 24 & 16 & 18 \\
\hline Information and & & & & & & \\
\hline communication technology & 40 & 25 & 31 & 41 & 30 & 28 \\
\hline Aircraft and spacecraft & 7 & 1 & 6 & 3 & 5 & 2 \\
\hline $\begin{array}{l}\text { Medical and health } \\
\text { engineering }\end{array}$ & 14 & 6 & 18 & 11 & 21 & 10 \\
\hline Micro/opto electronics, laser & 10 & 8 & 6 & 19 & 8 & 10 \\
\hline New materials & 21 & 47 & 14 & 55 & 25 & 52 \\
\hline $\begin{array}{l}\text { Production and process } \\
\text { engineering }\end{array}$ & 27 & 60 & 24 & 65 & 17 & 62 \\
\hline $\begin{array}{l}\text { Sensor engineering, } \\
\text { measuring, and control } \\
\text { technology }\end{array}$ & 23 & 22 & 16 & 40 & 19 & 31 \\
\hline Environmental engineering & 35 & 20 & 19 & 35 & 24 & 22 \\
\hline $\begin{array}{l}\text { Traffic and transport } \\
\text { engineering, logistics }\end{array}$ & 7 & 14 & 9 & 26 & 14 & 28 \\
\hline
\end{tabular}

Source: European Regional Innovation Survey.

a. Technology fields are in concordance with the ISI classification.

b. Percentage of research institutes cooperating intensively in the respective technology field with manufacturing firms.

c. Percentage of manufacturing firms cooperating intensively in the respective technology field with research institutes.

system. In contrast to the innovation system of Barcelona and Vienna, the Stockholm research institutes are very much engaged in technology fields that are new within the industrial fabric. In Barcelona and Vienna, the research institutes are much more engaged in technology fields with an existing industrial base. While the role of research institutes in Stockholm is more to push manufacturing firms into new and highly potential technology fields, research institutes in Vienna and Barcelona assist manufacturing firms in their technology fields to improve their own R\&D capabilities.

\section{SUMMARY}

The analysis of the three metropolitan regions Barcelona, Vienna, and Stockholm provides interesting insights into the innovative activity and innovation networking of the most important actors within regional innovation systems. Across the three metropolises, similarities and differences are visible. With respect to the 

More important than the simple repetition of results is the question of what conclusions can be derived to reorient regional policy toward innovation stimulation, thus improving metropolitan innovation systems. The results demonstrate that between regions of similar characteristics such as the three large metropolitan agglomerations surveyed, profound differences in technological competitiveness exist. It would be too simple to transfer the Stockholm success story to other locations. Regions are equipped with a specific set of production factors and influenced by a region-specific business environment (institutional arrangements, cultural and social context) that makes it difficult to derive generally valid policy recommendations. Also, limits of regional policy have to be admitted. Experience has shown that regional policy is more successful in stimulating existing innovation potentials and not so much in developing innovative regions from the very beginning (Sternberg 1998). However, the Stockholm example provides interesting insights into an innovation- and technology-oriented national and regional policy.

The Swedish national and regional R\&D promotion policy has shifted from the linear to the chain-linked innovation model. It stresses the need to improve the in-house R\&D capabilities via well-qualified personnel and external cooperation. The higher quality of human resources in Swedish firms, expressed in a higher proportion of R\&D personnel and personnel with academic training, enlarges the firms' innovation potential. The higher number of capable "heads" facilitates learning processes within a firm and increases the absorptive capacity for firm-external knowledge.

To improve innovation capabilities, the Swedish national and regional technology policy tries to encourage closer links between firms and research institutes. This does not mean the opening of an additional transfer agency as in many other countries. Here, on one hand, private firms, and on the other hand, public research institutes jointly establish research institutes with the aim to accelerate the process of transferring scientific findings into marketable products. In 1995, thirty industryrelated research centers affiliated with universities were established. In these centers of competence, researchers from industry and academia work together. The policy orientation toward business needs becomes also visible in measures against the expected labor shortage in the fields of engineering and natural science (reform of curricula to increase their attractiveness, longer financial support to students).

At the metropolitan level, the improvement of the business environment to stimulate innovative activities has a high priority. An outstanding example is the Kista science park, in which industry and public research institutes are linked closely together. Kista's focus is information technology (IT), and in 1998, the science park was ranked by the U.S. magazine Wired as the fifth best IT region in the world. Kista succeeded in establishing a network between public research institutions and small and large multinational companies (e.g., Ericsson, Nokia, Compaq, Microsoft, IBM, Hewlett-Packard, and Sun Microsystems).

Another positive example is the Business Arena Stockholm (BAS). BAS demonstrates that public entities can be flexible and creative. Here, twenty-four 
municipalities of the provinces Stockholm and Upssala have established jointly an economic promotion agency. Besides the attraction of foreign investment, BAS actively promotes firm start-ups in IT, medicine, and biotechnology. BAS offers a wide spectrum of business services free of charge to create a perfect business environment.

Undoubtedly, the metropolitan innovation system of Stockholm is a positive example of the advantages of innovation networking, resulting in an improved competitiveness, higher innovativeness, and dynamic economic performance. Although cooperation between industry and public research institutes cannot be forced, the Stockholm experience might be motivating other firms and regions to follow with a similar approach.

\section{REFERENCES}

Acs, Z., D. Audretsch, and M. Feldman. 1991. Real effects of academic research: A comment. American Economic Review 81: 363-67. $336-40$

Acs, Z., F. FritzRoy, and I. Smith. 2001. High technology employment and R\&D in cities: Heterogeneity vs specialization. Annals of Regional Science. Forthcoming.

Anselin, L., A. Varga, and Z. Acs. 1997. Local geographic spillovers between university research and high technology innovations. Journal of Urban Economics 42: 422-48.

Audretsch, D. B., and M. P. Feldman. 1999. Innovation in cities: Science-based diversity, specialization and localized competition. European Economic Review 43: 409-29.

Beise, M., and H. Stahl. 1999. Public research and industrial innovations in Germany. Research Policy 28: 397-422.

BMBF. 2000. Zur technologischen Leistungsfähigkeit Deutschlands. Zusammenfassender Endbericht, Bonn, Germany.

Braczyk, H. J., P. Cooke, and M. Heidenreich. 1998. Regional innovation systems. London: UCL Press.

Brouwer, E., H. Budil-Nadvornikova, and A. Kleinknecht. 1999. Are urban agglomerations a better breeding place for product innovation? An analysis of new product announcements. Regional Studies 33: 541-49.

Camagni, R. 1991. Innovation networks: Spatial perspectives. New York: John Wiley.

Charles, D., and J. Goddard. 1997. Higher education and employment—Linking universities with their regional industrial base. Paper prepared for the thematic seminar on Territorial Employment Pacts, 18-19 September, Ostersund, Sweden.

Cooke, P., and K. Morgan. 1993. The network paradigm: New departures in corporate and regional development. Environment and Planning D 11: 543-64.

Cooke, P., and K. Morgan. 1998. The associational economy: Firms, regions, and innovation. Oxford, UK: Oxford University Press.

Crevoisier, O. 1998. Innovation and the city. In Making connections-Technological learning and regional economic change, edited by E. J. Malecki and P. Oinas, 61-78. Aldershot, UK: Ashgate.

Davelaar, E. J., and P. Nijkamp. 1989. The role of metropolitan milieu as an incubation center for technological innovation: A Dutch case study. Urban Studies 26: 517-25.

De Bresson, C., and F. Amesse. 1991. Networks of innovators: A review and introduction to the issue. Research Policy 20: 363-79.

Edquist, C. 1997. Systems of innovation. Technologies, institutions and organizations. London: Pinter. 
Eurostat. 1999. Sechster periodischer Bericht über die sozio-ökonomische Lage und Entwicklung der Regionen der Europäischen Union, Amt für amtliche Veröffentlichungen der Europäischen Gemeinschaften, Luxembourg.

Ewers, H. J., and R. Wettmann. 1980. Innovation-oriented regional policy. Regional Studies 14: 161-79.

Fischer, M. F., J. Revilla Diez, F. Snickars, and A. Varga. 2001. Metropolitan systems of innovation-Theory and evidence from three metropolitan regions in Europe. Berlin, Germany: Springer.

Freeman, C., and L. Soete. 1997. The economics of industrial innovation. 3d ed. London: Pinter.

Fritsch, M., K. Koschatzky, L. Schätzl, and R. Sternberg. 1998. Regionale innovationspotentiale und innovative netzwerke. Raumforschung und Raumordnung 4: 288-98.

Harrison, B., M. R. Kelley, and J. Gant. 1996. Innovative firm behaviour and local milieu: Exploring the intersection of agglomeration, firm effects and technological change. Economic Geography 79: 233-58.

Howells, J. 1983. Filter-down theory: Location and technology in the UK pharmaceutical industry. Environment and Planning A 15: 147-64.

Hudson, R. 1999. "The learning economy, the learning firm and the learning region": A sympathetic critique of the limits to learning. European Urban and Regional Studies 6: 59-72.

Huggins, R. 1997. Competitiveness and the global region: The role of networking. In Innovation, networks and learning regions, edited by J. M. Simmie. London: Jessica Kingsley.

Jacobs, J. 1969. The economy of cities. New York: Random House.

Lakshmanan, T., and M. Okumura. 1995. The nature and evolution of knowledge networks in Japanese manufacturing: Papers in regional science. The Journal of the RSAI 74: 63-86.

Lundvall, B.-Å. 1992. National systems of innovation: Towards a theory of innovation and interactive learning. London: Pinter.

Malecki, E., and P. Oinas. 1998. Making connections-Technological learning and regional economic change. Aldershot, UK: Ashgate.

Maskell, P., H. Eskelinen, I. Hannibalsson, A. Malmberg, and E. Vatne. 1998. Competitiveness, localised learning and regional development. London: Routledge.

Nelson, R. 1993. National innovation systems - A comparative analysis. Oxford, UK: Oxford University Press.

Organization for Economic Cooperation and Development. 1999. Benchmarking the knowledge base economy. Paris: Organization for Economic Cooperation and Development.

Revilla Diez, J. 2000. The importance of public research institutes in innovative networks. Empirical results from the metropolitan innovation systems Barcelona, Stockholm and Vienna. European Planning Studies 8: 451-64.

Shefer, D., and A. Frenkel. 1998. Local milieu and innovations: Some empirical results. The Annals of Regional Science 32: 185-200.

Sternberg, R. 1998. Technologiepolitik und High-Tech Regionen-ein internationaler Vergleich. $2 \mathrm{~d}$ ed. Hamburg, Germany: Lit-Verlag.

Suarez-Villa, L., and M. M. Fischer. 1995. Technology, organization and export-driven research and development in Austria's electronics industry. Regional Studies 29: 19-42.

Varga, A. 1998. University research and regional innovation: A spatial econometric analysis of academic technology transfers. Boston: Kluwer. 